\title{
Juridical Study on the Optimization of Cash Waqf Management by Islamic Bank in Indonesia*
}

\author{
Teguh Tresna Puja Asmara**, Lastuti Abubakar*** \\ DOI: https://doi.org/10.22304/pjih.v6n3.a1
}

Submitted: September 15, 2019 | Accepted: December 02, 2019

\begin{abstract}
Cash waqf is an innovative instrument of waqf aiming to create social welfare. It is expected that cash waqf enables extensive public participation to support social welfare. However, in reality, cash waqf management in Indonesia has not yet resulted optimal benefit. Based on the Law Number 41 of 2004 on Waqf, three institutions carry out cash waqf management. They are the Indonesian Waqf Board as the collector and the developer, Nazhir as the manager, and the Islamic Financial Institution as the collector. The three institutions make the cash waqf management and development ineffective and not optimal. Based on the data from the Indonesian Waqf Board, of the total potential cash waqf IDR180 Trillion, only IDR400 billion was realized. This study is a normative juridical legal study employing descriptive method. The results reveal that the role of the Islamic Financial Institution, Islamic bank, as collector can actually be expanded. Thus, it covers the management and distribution roles like a Waqf Bank in Bangladesh, the Social Islami Bank Ltd. (formerly known as Social Investment Bank Ltd). Islamic bank has capability and professionalism of management and distribution of funds generated from the cash waqf.
\end{abstract}

Keywords: Cash Waqf, Islamic Bank, Optimization

\section{Studi Yuridis tentang Optimalisasi Manajemen Wakaf Uang oleh Bank Syariah di Indonesia}

\begin{abstract}
Abstrak
Wakaf uang merupakan salah satu instrumen inovatif dari wakaf dalam menciptakan kesejahteraan sosial di masyarakat. Dengan wakaf uang, partisipasi masyarakat umum akan terbuka lebih lebar dalam menunjang pemerataan kesejahteraan sosial. Akan tetapi, dalam kenyataannya pengelolaan wakaf uang di Indonesia masih belum dirasakan manfaatnya secara optimal. Berdasarkan Undang-Undang Nomor 41 Tahun 2004 tentang Wakaf, pengelolaan wakaf uang dilakukan oleh tiga lembaga yakni Badan Wakaf Indonesia (BWI) sebagai penghimpun dan pengembang, Nazhir sebagai pengelola, dan Lembaga

PADJADJARAN Journal of Law Volume 6 Number 3 Year 2019 [ISSN 2460-1543] [e-ISSN 2442-9325]

* This article is adapted from the author paper presented at Islamic Law Fair 2016, Diponegoro University.

** Student of Master Program at the Faculty of Law, Padjadjaran University, Jalan Banda No. 42, Bandung, S.H. (Padjadjaran University), Email: teguh13001@mail.unpad.ac.id.

*** Lecturer of the Faculty of Law, Padjadjaran University, Jalan Dipati Ukur No. 35, Bandung, S.H. (Padjadjaran University), M.H. (Padjadjaran University), Dr. (Padjadjaran University), Email: lastuti62abubakar@gmail.com.
\end{abstract}


Keuangan Syariah (LKS) sebagai penghimpun. Pengelolaan Wakaf Uang oleh tiga lembaga tersebut menjadikan pengelolaan dan pengembangan Wakaf Uang tidak efektif dan optimal. Hal ini terbukti dari data BWI, bahwa di tahun 2017 dengan total potensi Wakaf Uang keseluruhan yang mencapai Rp180 Trilyun, hanya terealisasikan sebesar Rp400 Milyar. Penelitian ini bersifat deskriptif analitis dengan menggunakan pendekatan yuridis normatif. Hasil penelitian menunjukan bahwa fungsi LKS dalam hal ini perbankan syariah sebagai penghimpun wakaf uang, sesungguhnya dapat diperluas sehingga mencakup fungsi pengelolaan dan penyaluran seperti Bank Wakaf yang ada di Bangladesh yakni Social Islami Bank Limited (sebelumnya dikenal sebagai Social Investment Bank Ltd). Perbankan syariah memiliki kompetensi dan profesionalisme dalam pengelolaan dan penyaluran dana yang berasal dari wakaf uang tersebut.

Kata kunci: Optimalisasi, Perbankan Syariah, Wakaf Uang

\section{A. Introduction}

The Preamble of the 1945 Constitution of Indonesia states that one of the national objectives of the people of Indonesia is public welfare. This objective is based on economic democracy by relying on a fair market mechanism. ${ }^{1}$ To achieve the ideal, the State needs to play an active role in carrying out national economic development by making efforts to renew the economic legal system to be suitable with the values that live within society

In the fields of law and justice, Indonesia is the largest Muslim country in the world that cannot be separated from Islamic law. In the context of national economic development, Islamic Law is urgently needed to be the foundation of economic activities within society adhering to Islamic values such as cooperation, tolerance, and justice. The existence of Islamic economic law in the national economic legal system was strengthened by the enactment of the Islamic Law system in banking activities with the presence of Islamic bank. Therefore, Indonesia has dual legal system governing the same material. ${ }^{2}$

The enactment of the Law Number 41 of 2004 on Waqf is a form of Islamic Law in the field of economy to achieve the welfare objective. The utilization of waqf is not only for the purposes of ceremonial worship but also carries out social functions for equal distribution of public welfare. The principles of waqf management are to maintain the eternity of the substance of property and to maximize the results. They are effective means of realizing public welfare.

The existence of waqf has the potential to continue to be developed in Indonesia. Realizing the potential, the Indonesian Government establishes efforts to regulate waqf. Initially, the Law on Waqf and Government Regulation Number 42 of 2006 on the Implementation of the Law Number 41 of 2004 on Waqf was

\footnotetext{
Syaugi Mubarak, "Demokrasi Ekonomi dalam Hukum Ekonomi Syari'ah", Risalah Hukum Fakultas Hukum Unmul, Vol. 6, No. 2, 2010, p. 89.

2 Lastuti Abubakar and Tri Handayani, "Perkembangan Transaksi Perbankan dan Implikasinya terhadap Pembaruan Hukum Perdata Indonesia", Justitia Jurnal Hukum, Vol. 1, No. 2, 2017, p. 251.
} 
enacted. Subsequently, it has been amended by the Government Regulation Number 25 of 2018 on the Amendments of Government Regulation Number 42 of 2006 on the Implementation of the Law Number 41 of 2004 on Waqf.

Currently, people's understanding of waqf is still very restricted on physical goods, such as Land or Building. Consequently, the benefit on economic welfare is limited. In fact, even though waqf is a Maliyah ${ }^{3}$ instrument, it can also be classified as a humanitarian effort. ${ }^{4}$ Therefore, Waqf must be maximized to realize public welfare.

Cash waqf is an innovative instrument of waqf to realize public welfare. It enables public participation to support the equitable distribution of public welfare. The Law on waqf based on ljtihad can be understood as the development of the provision. Despite the fact that cash is not mentioned directly in the valid texts, the Holly Quran and Hadith, as a form of waqf, Islamic scholars have no dissenting opinion regarding the practice of cash waqf. The difference is only in the sense of the essence that must be eternal or not about assets that may be represented. ${ }^{5}$ Thus, the law of cash waqf is included in the concept in which appropriate with the thoughts of Malikiyah and Hanafiyah scholars wherein the treasure of waqf category can also include the items that may not always be perpetual. In this case, the analogy against the law of mubah (be allowed) turn out to be appropriate for relevance to the position of the cash waqf based on the principle that all the problems are basically mubah as long as there is no argument that prohibits it.

Cash waqf also has the potential to advance the national economy. According to Nasution, the potential is estimated to reach three trillion in a year. ${ }^{6}$ However, the management of the cash waqf is still not reach the peak. According to data from the Indonesian Waqf Board (BWI - Badan Waqaf Indonesia), in 2017, of the potential IDR180 trillion, only IDR400 billion was realized. ${ }^{7}$ This is undeniably very far from the calculation. As a modification of Waqf, the cash waqf management cannot be treated equally with the general waqf management. Because of the differences with waqf management in general, problems or obstacles often arise in the management institutions and developers of cash waqf. Under the Law on Waqf, there are three parties acting as cash waqf managers and developers. They are the BWI, Nazhir, and the Islamic Financial Institutions. The division of management and development of cash waqf into these three different institutions

\footnotetext{
Maliyah Instruments or Maliyah Worship, is the deed of worship carried out by means of property or manifested in the form of giving assets or related to assets, such as Waqf, Zakat, Infaq, and Shadaqa.

$4 \quad$ Ali Amin Isfandiar, "Tinjauan Fiqh Muamalat dan Hukum Nasional tentang Wakaf di Indonesia", La Riba, Vol. 2, No. 1, 2008, p. 52.

Imam Suhadi, Wakaf Untuk Kesejahteraan Umat, Yogyakarta: PT. Dana Bhakti Prima Yasa, 2002, p. 80. Ibid.
}

Umi Nur Fadhilah, "Potensi Wakaf Tunai Capai Rp 180 Triliun”, Republika, https://www.republika.co.id/berita/dunia-islam/wakaf/18/10/16/pgovmd384-potensi-wakaf-tunai-capai-rp180-triliun, accessed on 02 November 2018. 
has led to the failure of cash waqf in Indonesia. Another problem is the competency of cash waqf management that cannot accommodate all interests.

As a step to realize social welfare, optimization of cash waqf needs to be done in a structured, systematic, and massive manner. Institutional waqf is important to realize the optimization of cash waqf in Indonesia. Therefore, an exclusive management institution should include collection and distribution. Therefore, obstacles and constraints of the role of cash waqf can be addressed effectively and efficiently. The potential of Islamic Financial Institutions as the collector of cash waqf, as regulated in the Law on Waqf, can actually be expanded so that it also covers the management and distribution functions because the Islamic Financial Institutions have competence in collection and management of professional social funds. Based on the background, this study aims to analyze the revision of regulations to facilitate the Islamic bank to become Nazhir as an effort to optimize cash waqf in Indonesia.

This study used normative juridical approach method that prioritizes library research to be secondary data material in the form of positive law in this case governing the cash waqf and Islamic bank. ${ }^{8}$ The normative juridical approach method used in this study includes research on the legal principles, legal systematics, and legal synchronization. ${ }^{9}$ This research is descriptive method of analysis which describes the facts of the data obtained based on reality in this case the implementation of cash waqf in Indonesia. These facts are then analyzed by the applicable law and conclusions are drawn. The research phases are carried out in two stages, the first is Library Research, this study aims to examine and trace secondary data in the form of primary, secondary and tertiary material. The second is Field Research, this research is conducted to obtain primary data in the field as a result of secondary data collection and interviews with practitioners, academics and other professionals who have competence with research material in legal writing.

\section{B. Cash Waqf as Waqf Innovation}

Etymologically, waqf is derived from the word waqafa-yaqifu-waqfan, which means to stop or to hold (al-habs). ${ }^{10}$ Terminologically, Islamic scholars have provided the definition of Waqf. A scholar of Shafi'i School, Imam Nawawi, mentions that Waqf is to hold back the assets that can be taken advantage of, while the object remains and the benefits are used for good and draws closer to Allah. According to a scholar of the Hanafi School, Imam Syarkhasi, waqf is to hold back property from the reach

Soerjono Soekanto and Sri Mamudji, Penelitian Hukum Normatif: Suatu Tinjauan Singkat, Jakarta: PT. Raja Grafindo Persada, 2003, p. 13.

Soerjono Soekanto, Pengantar Penelitian Hukum, Jakarta: Penerbit Universitas Indonesia 2008, p. 51.

10 Said Agil Husin al-Munawwar, Hukum Islam dan Pluralitas Sosial, Jakarta: Penamadani, 2004, p. 122. 
of other people. Ibn Arafah of the Maliki School defines Waqf as provision of something, at the time limit of its existence, at the same time as an estimate. ${ }^{11}$

According to the Indonesian Compilation of Islamic Law (KHI -Kompilasi Hukum Islam), Waqf is a legal act of a person or group of people or legal entity that separates part of property and institutionalizes it eternally for the interests of worship or other public purposes in line with Islamic teaching. Furthermore, the Law Number 41 of 2004 on Waqf states that waqf is a legal act of a wakif to separate and/or to submit a portion of property to be used evermore or for a certain period in accordance with interests for the purposes of worship and/or public welfare based on sharia. Article 16 Paragraph (3) regulates Waqf property not only limited to immovable objects; it also covers movable objects such as money, precious metals, securities, vehicles, intellectual property rights, rights of lease, rights of movable objects, and further movable objects based on Islamic laws and applicable laws and regulations.

Initially, waqf assets that have been deemed in a narrow manner include only immovable property such as land and buildings. However, the coverage is developed to include movable property such as cash. In accordance with the fatwa of the Indonesian Ulema Council (MUI -Majelis Ulama Indonesia) on May 11, 2002, the Waqf (al-Nuqud Waqf/Cash Waqf) is a waqf by a person, a group of people, an institution, or a legal entity in the form of cash. This is one of the productive Waqf. Didin Hafidhuddin, in Anshori, ${ }^{12}$ explains that productive Waqf is a gift in the form of something that can be cultivated or rolled out for the good and benefit of people.

The cash waqf is similar to other Islamic financial instruments, namely zakat, infaq, and shadaqa (ZIS). Still, there are some differences between them. Unlike the cash waqf, ZIS can be distributed directly to the beneficiary. On the contrary, cash waqf should be invested so that people always have available funds that increase along with the increase in the number of wakif who do charity. The investment profits from the principal can be reused to fund the needs of people. Therefore, the cash waqf instrument can be a public fundraising instrument.

Essentially, Waqf is charity from benefits and profits obtained from the assets of Waqf with the provision of holding object not to be traded, granted, and inherited to remain lasting (dawam al-intifa). The reward continues to flow to the wakif. The eternal principle of benefits is the main principle of waqf. ${ }^{13}$

The Law of cash waqf can be understood as the development of thought from the original provision. The cash waqf is not mentioned in the Holy Quran and the Hadith. However, there is no difference of opinion among scholars in the practice of waqf. The dissenting opinion (khilafiah) only covers whether the asset must be

Elsi Kartika Sari, Pengantar Hukum Zakat dan Wakaf, Jakarta: Grasindo, 2007, p. 55.

Abdul Ghofur Anshori, Hukum dan Praktik Perwakafan di Indonesia, Yogyakarta: Pilar Media, 2006, p. 90.

Rashedul Hasana and Siti Alawiah Siraj, "Complexities of Waqf Development in Bangladesh", Journal of

Emerging Economies and Islamic Research, Vol. 4, No. 3, 2016, p. 19. 
eternal or not. ${ }^{14}$ Therefore, the law of cash waqf is included in the understanding of the Schools of Malikite and Hanafite that allow the asset of Waqf also to include items that may not always be eternal. In this case, the analogy to the law of mubah (be allowed) turn out to be appropriate to the position of cash waqf based on the principle that all things are basically mubah as long as there is no prohibition.

\section{Cash Waqf as a Representation of Economic Democracy}

The Economic Democracy System is an economic system that refers to the mandate of the national constitution. According to Article 33 of the 1945 Constitution, the Economic Democracy System is based on society's, not individual, prosperity. It is structured as a joint effort based on the principle of kinship.

National economic development must be sustainable based on economic democracy. ${ }^{15}$ The Economic Democracy System involves all strengths of people's economy. Therefore, it needs to be held not only as an alternative but as the main of the economic system of a nation. According to Baswir, ${ }^{16}$ the economic democracy can be defined as a national economic system that is structured as a joint venture based on the principle of kinship, where the production is carried out by all, for all, under the leadership or surveillance of society members to increase the ability of the society to control the economy. To be precise, it is an economic governance aiming to achieve people's welfare and economic democracy progressan overall economic activity carried out by modest people. ${ }^{17}$

Essentially, the principle is in line with the practice of waqf of Islamic economy. The main purposes of both systems are welfare and economic justice for everyone. ${ }^{18}$ The assets of waqf, as an Islamic social institution, essentially carry a function of economic resource. This means that the use of waqf assets is not only limited to the needs of conventional activities, such as education, mosques, hospitals, orphanages, and others. The assets of Waqf, in a broader sense, can be used for economic activities, such as agriculture, livestock, industry, mining, real estate, offices, hotels, restaurants, and others.

Cash waqf is one of the potential economic resources that are closely related to the welfare of the people (ummah). The other resources, to be mentioned, consist of zakat, infaq, and shadaqa. It is spiritual institution that is closely related to socioeconomic conditions. In general, waqf has significantly the developments of human resources and socio-economic resources.

Imam Suhadi, op.cit., p. 80.

15 Teguh Tresna Puja Asmara, Isis Ikhwansyah, and Anita Afriana, "Ease of Doing Business: Gagasan Pembaruan Hukum Penyelesaian Sengketa Investasi di Indonesia", University of Bengkulu Law Journal (UBELAJ), Vol. 4, No. 2, 2019, p. 126.

16 Revrisond Baswir, Ekonomi Kerakyatan sebagai Sistem Indonesia, Yogyakarta: Pustaka Pelajar, 1995, p. 111. Ibid.

18 Sofyan Rizal, "Titik Temu dan Sinergi Ekonomi Islam dan Ekonomi Kerakyatan", Al-lqtishad, Vol. 3, No. 1, 2011. 
Juridical Study on the Optimization of Cash Waqf Management by Islamic Bank in Indonesia

\section{The Function and Role of Islamic Bank in Economic Development}

Well-structured financial management patterns strongly influenced economic development of a country. Financial management, especially banking, is an effort to realize national development. In general, banks manage public fund in a structured and institutionalized state. A bank is an institution that aims to satisfy the needs of people for credit, both with money (funds) received from other people, and by circulating money in the form of common money and check. ${ }^{19}$

Banking system continues to develop and currently presenting a form called Islamic bank, which uses the principles of Islamic values based on the National Legal System. According to Article 1 point 7 of the Law Number 21 of 2008 on Islamic Banking, Islamic bank carries out their business activities based on Islamic Principles; and, according to their type, it consists of Islamic Commercial Banks and Public Islamic Financing Banks. The Islamic Principles referred to above are part of Islamic teachings related to economy based on the values of justice, expediency, balance, and universality (rahmatan lil 'alamin).

Both conventional and Islamic banks in general have almost similar purpose. Based on Article 4 of the Law Number 7 of 1992 on Banking, which has been amended by the Law Number 10 of 1998, the objective of Indonesian Banking is to support the implementation of national development to increase equity, economic growth, and national stability towards increasing people's welfare. To improve the distribution of public welfare, Islamic bank is based on economic democracy, the principle of prudence, while maintaining justice and togetherness. In other words, in addition to be an agent of development maintaining monetary stability, Islamic bank also strives to maintain the economy, which is bound by aqeeda, sharia, and moral values as well as to create a balance between individual and universal objectives. $^{20}$

The functions of bank in general determine its activities. They include collecting and distributing public funds. Besides the mandatory functions, Islamic bank have a social function in receiving funds from Zakat, Infaq, Shadaqa, Waqf, etc. Furthermore, Article 4 Paragraph (3) explains that Islamic banks can collect social funds originating from the cash waqf and distribute them to the Nazhir in accordance with Wakif's will.

The Government must consider an important solution to recover Indonesia's economy by the implementation of Islamic economy. One of the efforts is the management of Islamic bank. The Islamic economy principles, compared to conventional banking systems, contain excellent concepts to deal with monetary fluctuation. The global economic experts such as Rodney Shakespeare, Volker Nienhaus, and others recognized the Islamic Economy to be effective and resistant in times of crisis. ${ }^{21}$ Based on the principle of profit sharing offered, Islamic bank

\footnotetext{
Syamsuddin Mahmud, Dasar-Dasar Ilmu Ekonomi dan Koperasi, Banda Aceh: PT. Intermasa, 1986, p. 194. Mardani, Hukum Ekonomi Syariah di Indonesia, Bandung: Refika Aditama, 2011, p. 12.

Ibid.
} 
forms a healthy and fair investment climate because all parties can share both benefits and risks so that banks and its customers gain a balanced position. In the future, it could encourage national economic equality because both capital owner and capital managers enjoy profits.

\section{E. Social Islami Bank Limited (formerly known as Social Investment Bank Ltd) as the Model of Waqf Bank}

Social Islami Bank Limited (SIBL), formerly known as Social Investment Bank Ltd., is a model of bank that covers three service sectors: formal, informal, and voluntary aiming to alleviate poverty and empower families through social investment based on participatory economics. ${ }^{22}$ The SIBL's banking and financial activities use a humanitarian approach and operationalization based on interest-free transactions through financing and participation..$^{23}$ The SIBL offers socio-economic programs in the form of a spirit of sharing and participation, social responsibility, and mutual needs. This concept avoids individualistic behavior to produce loyalty as the concept of essential economic democracy. The SIBL also offers modern banking services with the deposit concept. In the concept, depositors participate in various financing model activities and some investments projects such as profit-sharing projects, trade leasing projects, lease purchase agreements etc. These projects do not only reflect economic activity but also as social and moral activities.

The SIBL was pioneered by Bangladesh's leading Islamic economist, Prof. Dr. M. A. Mannan, who introduced the Cash Waqf Certificate as a new voluntary product in the history of the voluntary banking sector. This Cash Waqf Certificate is used as a financial instrument in the banking sector to manage social funds, including Waqf funds. The SIBL's operation receives cash waqf as donation based on Islamic teaching. Their role is to manage the waqf in the name of Wakif. The Wakif has the freedom to choose the objective or the target of the waqf in line with the list provided by SIBL or other objectives permitted by Islamic teachings. Against the quantity of the waqf, it must remain intact and only the profits are spent on the wakif's objectives. The profits that are not spent is automatically added to the Waqf so that the profits always increase. Afterward, the cash waqf deposit is given a receipt or, after the amount of the waqf reaches the specified amount, the certificate is issued. ${ }^{24}$

The establishment of SIBL through its Cash Waqf Certificate provides latest paradigm for waqf that opportunities for representation are not only for rich people but also for all people in general. The role of cash waqf is very important to sustain national development efforts by increasing society participation. The SIBL

22 M. A. Mannan, "Cash-waqf Certificate: Global Opportunities for Developing the Social Capital Market in 21st -Century Voluntary-sector Banking," Third Harvard University Forum on Islamic Finance, Harvard University, 2011, p. 6.

23 Jafril Khalil, "Social Investment Bank Limited (SIBL) di Bangladesh", Al-Awqaf, Vol. II, No. 02, 2009, p. 56.

$24 \quad$ Ibid, p. 56. 
Juridical Study on the Optimization of Cash Waqf Management by Islamic Bank in Indonesia

also makes the role of banks as facilitators to optimize the development and management of cash waqf to realize its goal.

The SIBL basically has a model that is very adaptable and can be applied in both Muslim and non-Muslim states that wish to eradicate poverty by avoiding interest that have strangled people's lives. In Bangladesh, the SIBL provides new experiences within the framework of poverty alleviation through society participation and their role as the initiator of the establishment of waqf banks in various countries, including Indonesia.

\section{F. The Implementation of Cash Waqf in Advancing the Economic Democracy}

The Economic Democracy System is an economic system that refers to the mandate of the national constitution. Article 33 of the 1945 Constitution states that the Economic Democracy system is based on the prosperity of society, not individual. This is structured as a joint effort based on the principle of kinship.

As the economic democracy system that involves all strengths of people's economy, it needs to be the main of the economic system of a nation, not only as an alternative. According to Baswir ${ }^{25}$, the economic democracy is a national economic system that is structured as a joint venture based on the principle of kinship, where production is carried out by all, for all, under the leadership or surveillance of members of society to increase the ability of the society to control the economy. In other words, the management of economic democracy is the implementation of an economy that affects the welfare of people. The progress of the economic democracy lies on overall economic activities that are carried out by people. $^{26}$

Essentially, the system is in line with the practice of Waqf. Both place welfare and justice of economy for everyone as the main objective. ${ }^{27}$ The assets of waqf can be used as an economic resource. This means that the use of the waqf asset is not only limited to the needs of conventional activities, such as education, mosques, hospitals, orphanages, etc. The assets can also be used for economic activities, such as agriculture, livestock, industry, mining, real estate, offices, hotels, restaurants, etc. Cash waqf is a potential economic resources that is closely related to the welfare of the people, in addition to zakat, infaq, and shadaqa.

Prior to formal legal arrangement, on May 11, 2002, the MUI released a fatwa that the law of cash waqf was jawaz (allowed). Based on the fatwa, the Nazhir Waqf institutions were established to accommodate collection and management of cash waqf. They consisted of Tabung Wakaf Indonesia (TWI), Pos Keadilan Peduli Umat (PKPU), and Baitul Mal Muamalat (BMM). ${ }^{28}$ The existence of the waqf, after

\footnotetext{
Revrisond Baswir, Ekonomi Kerakyatan sebagai Sistem Indonesia, Yogyakarta: Pustaka Pelajar, 1995, p. 111. Ibid.

Sofyan Rizal, "Titik Temu dan Sinergi Ekonomi Islam dan Ekonomi Kerakyatan", Al-lqtishad, Vol. 3, No. 1, 2011, p. 10.

28 Muhyar Fanani, “Pengelolaan Wakaf Tunai”, Jurnal Walisongo, Vol. 19, No. 1, 2011, p. 180.
} 
the establishment of the waqf Law, was then realized by three institutions. The first is $\mathrm{BWI}$ as an independent government agency to develop the waqf system in Indonesia, the appointment of Islamic Financial Institutions as an institution to collect the cash waqf and nazhir as the waqf manager. However, this management mechanism was not able to optimize the potential of cash waqf in Indonesia. The management of waqf funds under many parties resulted in less effective management of cash waqf up to now. Based on the data from the BWI, of the total potential cash waqf IDR180 Trillion, only IDR400 billion was realized. ${ }^{29}$ According to Nasution, the potential for cash waqf in Indonesia ranges from around IDR3 trillion.

Table F.1 : Potential of Cash Waqf ${ }^{30}$

\begin{tabular}{|l|l|l|l|l|}
\hline $\begin{array}{l}\text { Income } \\
\text { Level/Month }\end{array}$ & $\begin{array}{l}\text { The Amount of } \\
\text { Muslim }\end{array}$ & $\begin{array}{l}\text { Time Rate/ } \\
\text { Month }\end{array}$ & $\begin{array}{l}\text { Potential of } \\
\text { Cash Waqf/ } \\
\text { Month }\end{array}$ & $\begin{array}{l}\text { Potential of } \\
\text { Cash Waqf/ } \\
\text { Year }\end{array}$ \\
\hline $\begin{array}{l}\text { IDR500.000 } \\
\text { IDR1 million } \\
-\quad \text { IDR2 } \\
\text { million }\end{array}$ & 3 Million & IDR5000 & IDR20 Billion & $\begin{array}{l}\text { IDR240 } \\
\text { Billion }\end{array}$ \\
\hline $\begin{array}{l}\text { IDR2 million } \\
-5 \text { million }\end{array}$ & 2 Million & IDR10.000 & IDR30 Billion & $\begin{array}{l}\text { IDR360 } \\
\text { Billion }\end{array}$ \\
\hline $\begin{array}{l}\text { IDR5 million } \\
-10 \text { million }\end{array}$ & 1 Million & IDR50.000 & IDR100 Billion & $\begin{array}{l}\text { IDR1,2 } \\
\text { Trillion }\end{array}$ \\
\hline \multicolumn{2}{|l|}{ TOTAL } & IDR100.000 & IDR100 Billion & $\begin{array}{l}\text { IDR1,2 } \\
\text { Trillion }\end{array}$ \\
\hline
\end{tabular}

Based on the Table F.1 and by looking at the goals and contributions that can be provided by the Waqf institution, the existence of Cash Waqf in Indonesia, especially in realizing social welfare, is very crucial. Masyita ${ }^{31}$ reveals that if the waqf fund collection increases, for example, around IDR50 million in a day, assuming that the collected funds are constant, the development of cash waqf has an economic strategy value in overcoming poverty for 11,000 days (30 years) and 21,000 days (57 years) to improve the quality of Indonesian population. Different simulation models can be built up on various assumptions for mobilization of Cash Waqf Fund. For example, Cash Waqf of one US dollar per Muslim in one month can generate US\$1.6-billion, US\$260 million in Indonesia, US\$160 million in

Umi Nur Fadhillah, loc.cit.

Mustafa Edwin Nasution, Wakaf Tunai dan Sektor Volunteer, Jakarta: PSTTI-UI, 2006, pp. 43-44.

31 Dian Masyita, (et.al), "A Dynamic Model for Cash Waqf Management as One of The Alternative Instruments for the Poverty Alleviation in Indonesia", The 23rd International Conference of The System Dynamics Society, Boston, 17-21 July 2005, p. 28. 
Bangladesh, US\$176 million in Pakistan, US\$80 million in Turkey, and US\$30 million in Malaysia, etc. ${ }^{32}$

Cash waqf needs to be managed by competent and professional institution so that the purpose to improve social welfare can be realized. The presence of TWI, PKPU, BMM, and other Nazhir organizations or institutions actually reflects the form of independent institution in the management of the Indonesian Cash Waqf System. However, the institutions currently still have obstacles in the managerial operational of the Cash Waqf System. Nazhir as an asset manager currently has not been carried out professionally. For instance, one of the tasks is to carry out the obligation to secure principal assets but the institutions have not involved in Islamic deposit insurance..$^{33}$ In addition, the BWI has too many functions and authorities, including regulation, supervision, socialization, management, collection, and distribution. The BWI functions as the main nazhir manager become inefficient and lack of effectiveness in socializing and collecting cash waqf. In fact, the two important functions can be the key point to success.

There is also an overlap of authority, especially between the regulatory function and the management function. As the manager, BWI has the role to manage and develop waqf assets. Unfortunately, BWI has also regulatory authority both for itself, as the manager, and for the Nazhir. This is inappropriate because the function of regulation and management should not be in one body. Thus, the overlapped authority causes the management of Cash Waqf ineffective.

According to Article 28 of the Law on Waqf ${ }^{34}$, fundraising can be done through Islamic Financial Institutions. However, the optimization of cash waqf as a means of social welfare is hampered. In the Indonesian waqf system, the LKS-PWU only serves as the "recipient" of the cash waqf based on the mandate of the Law. The Management function is still limited to the Religious Social Institutions. Therefore, the LKS-PWU does not take an active attitude and tends to be passive in capturing Wakif because the determination of the forms of Waqf management and its designation is not their authority. This then affected the level of productivity of the waqf because the LKS-PWU is unable to explain concretely and clearly the allocation of collected Waqf. ${ }^{35}$

The roles of waqf institutions, in the form of regulators, collector, managers, and distributors, that are shared between the BWI and the Ministry of Religion, the Ministry of Religion and the Coordinating Ministry for Economic Affairs, BWI with

32 M. A. Mannan, "Linking Islamic Commercial and Social Finance with Special Reference to Cash-Waqf as New Strategy of Interest-Free-Micro-Credit for Family Empowerment of The Poor Towards Establishing World Social Bank: A Case Study Approach", Journal of Islamic Monetary Economics and Finance, Vol. 3, Special Issue, 2018, p. 9.

33 Muhyar Fanani, op.cit., p. 192.

34 See Article 28 of the Law Number 41 of 2004 on Waqf.

35 Ahmad Furqon, "Analisis Praktik Perwakafan Uang pada Lembaga Keuangan Syariah", Jurnal Walisongo, Vol. 19, No. 1, 2011, p. 159. 
LKS-PWU, have not been aligned. They are still running partially. ${ }^{36}$ Therefore, the management of Waqf must be carried out under one institution to accelerate and make simple the system. An integrated institution performing waqf system can be effective and optimal. In addition, it should be noted that the management of cash waqf is different with conventional waqf.

\section{G. Legal Studies on the Position of Cash Waqf in Indonesian Waqf System}

Since waqf is an instrument originating from Islamic Law, the discussion must always involve Islamic Law. The word waqf comes from Arabic, which means to stop or stand up. According to the Law, waqf is to hold back assets without spending or damaging the object that is used for good purposes. In general, waqf is a gift that is carried out by holding the original ownership (tahbisul ashli) so that the benefits can be received generally. Tahbisul Ashli holds goods that are not inherited, leased, and mortgaged to others. The goods may be used based on the will of the wakif without compensation.

In Indonesia, waqf has been known since before the independence. Moreover, Indonesians have known it since the early days of Islam in Indonesia. In the independence era, Waqf has received more attention so that it accommodated in the Law on Waqf. Previously, it was regulated in Book III of the Compilation of Islamic Law on Waqf.

Provisions regarding property or goods that can be represented are explained in the Law. Specifically, Article 16 Paragraph (1) reads that property can be in the form of either immovable or movable properties or goods. Cash Waqf is a type of Waqf that is regulated in the Law specifically. The inclusion and arrangement of cash waqf in the Law is based on the fatwa MUI on May 11, 2002 on cash waqf as follows.

1. Cash waqf (al-nuqud waqf) is a waqf by a person, group of people, institution, or legal entity in the form of cash.

2. Securities can be included in cash waqf.

3. The principle of cash waqf is jawaz (allowed).

4. Cash waqf can only be distributed and used for things that are allowed by Islamic principle.

5. The principal value of waqf must be guaranteed for sustainability. The goods or property cannot be sold, granted, and/or inherited.

The MUI has released a fatwa on the status of cash waqf and it is adopted into the Government Regulation Number 42 of 2006 on the Implementation of the Waqf Law. In the Regulation, cash waqf is given a narrow meaning covering only cash in the form of Rupiah. If the money is not Rupiah, or in foreign currency, the money must be converted first.

$36 \quad$ Ibid, p. 64. 
Juridical Study on the Optimization of Cash Waqf Management by Islamic Bank in Indonesia

The regulation also arranges requirements of wakif as follows:

1. Wakif presents at the LKS-PWU to declare the cash waqf;

2. Wakif explains ownership and origin of money;

3. Wakif deposit cash to the LKS-PWU; and

4. Wakif fills out form containing the statement of intention, which functions as the Waqf Pledge Deed.

Regarding the right to manage waqf, the Law of Waqf mentions that the party entitled to manage the waqf is nazhir. Article 9 divides nazhir into three types: individual, organization, and legal entities. To develop waqf in Indonesia, the Law regulates that an independent institution is formed as the main institution that manages waqf. It is the Indonesian Waqf Board (BWI -Badan Wakaf Indonesia). The BWI is based in the capital state of the Republic of Indonesia and can form representatives in provinces and/or districts/cities according to their needs. As the main institution, BWI has several functions to develop waqf. Article 49 Paragraph (1) reads that it is to:

(1) nurture nazhir in managing and developing waqf properties;

(2) manage and develop national and international waqf assets;

(3) give approval and/or permission for changes in designation and status of waqf property;

(4) dismiss and replace nazhir;

(5) give approval for the exchange of Waqf property;

(6) provide advice and consideration to the Government in the formulation of policies in the field of waqf.

Article 28 to Article 31 specifically regulates the management of general and cash waqf. Cash waqf must be deposited in Sharia Financial Institution Receiving Cash Waqf (LKS-PWU -Lembaga Keuangan Syariah Penerima Wakaf Uang). The Minister of Religious Affairs of the Republic of Indonesia determines the institution. The Islamic Financial Institution is Indonesian legal entity formed in accordance with the applicable laws and regulations that are engaged in Islamic finance-for instance, an Islamic bank. The possibility of moving cash waqf into Islamic Financial Institution is intended to enable wakif to gather the cash easier.

The Minister determines the LKS based on advice and consideration from the BWI. Previously, the selected LKS-PWU have several tasks. First, the LKS-PWU announce their existence publicly through various means of communication. Subsequently, the LKS-PWU can receive written statement from wakif containing statement of intention. After the waqf is received, the money is placed in a deposit account (wadi'ah) in the name of nazhir. The LKS-PWU is also obliged to provide a blank Certificate of Cash Waqf (SWU -Sertifikat Wakaf Uang) to be issued and submitted to wakif as a proof of Waqf submission. The copy is submitted to nazhir who is appointed by wakif. According to Indonesian Waqf Board Regulation 
Number 01 of 2009, the certificate can be given to wakif who has donate the money of at least Rp1.000.000 (one million Rupiah) by including a description of the origin of the money and the complete identity of the wakif. To be concluded, LKS-PWU must register cash waqf to the Minister on behalf of nazhir.

Essentially, the status and the arrangement of cash waqf is clear and has a strong legal basis for further development. Unfortunately, in the practice, cash waqf management still faces various obstacles ranging from technical management, community paradigms, and internal problems of cash waqf management-institution.

\section{H. Juridical Research on the Optimization of Cash Waqf Management by Islamic Bank in Indonesia}

In terms of regulation and legal aspects of cash waqf, Indonesia is very detail. The management of cash waqf under the Law on Waqf determines that three parties involve in managing cash waqf. First, it is the BWI to manage and develop. Second, Islamic Financial Institutions acts to collect and distribute fund. Third, Nazhir is the cash waqf fund manager.

In fact, the management of waqf through a single institution has not been effective and efficient. Therefore, the potential of cash waqf has not been optimized yet. Many people cannot feel the benefits of cash waqf, which has the potential to reach 3 trillion per year.

Islamic bank that acts as the nazhir, or waqf bank, can be a solution to overcome the problems related to cash waqf. Bank system enables the utilization of bank function in terms of professional fund management, public trust, and the reach of bank that has many branches to socialize cash waqf.

According to Mannan, Waqf Bank is a bank that holds waqf in the form of cash waqf. In this case, it could turn as a supplement to fund various social projects. ${ }^{37}$ The waqf bank shall have full authority as nazhir that performs tasks to receive, to manage, and to distribute waqf funds. It is possible based on Article 9 of the Law on Waqf, which states that Nazhir can also be an organization or a legal entity.

The bank that can be a waqf bank in Indonesia is an existing Islamic bank that receives expansion of authority not only to become a fund collector but also to manage and distribute cash waqf. Based on the Law Number 21 of 2008 on Islamic bank, Islamic bank is a bank that carry out their business activities based on Islamic Principles. According to the type, there are Islamic Commercial Banks and Islamic Society Financing Banks. Both are to support the implementation of national development to improve justice, togetherness, and equal distribution of people's welfare. The definition and purpose of Islamic bank is in line with the definition of waqf bank, which also aims to improve the welfare of society.

\footnotetext{
37 F. Prihatini, (et.al.), Hukum Islam Zakat dan Wakaf, Jakarta: Collaboration between the Papas Sinar Mentari Publisher and the University of Indonesia's Faculty of Law Publishing Board, 2005, p. 151.
} 
Islamic bank currently has a social function to collect cash waqf. However, the social function has not been able to optimize cash waqf in Indonesia because trustworthy and professional institution must collect it. The role of Islamic bank to manage cash waqf has at least several advantages to optimize waqf as follows:

1. Islamic bank's network is wider compared to other Islamic Financial Institutions. This is an important factor to optimize socialization of waqf collection and distribution.

2. Bank has an ability to be a fund manager. A bank is a public fund management institution. It has the ability to manage funds and is expected to be able to act as an alternative institution capable of managing cash waqf funds to be accounted to the public, especially wakif.

3. The facilities of several Islamic banks are relatively complete. For instance, the availability of widely spread cash machine networks, SMS Banking, Internet Banking, Phone Banking, and auto debit facilities from customer accounts can make it easier for people to make cash waqf deposits. Currently Islamic banks have more than 10,000 cash machine facilities.

4. Professional human resources in Islamic Banks guarantee that waqf funds are received and managed optimally, reliably, honestly, and transparently. They are expected to maximize the benefits of managing cash waqf.

5. Cash waqf funds, either in the form of nazhir deposit funds (wadi'ah) or nazhir managed funds (mudharabah) are part of the third-party funds of Islamic banks guaranteed by the Indonesia Deposit Insurance Corporation (IDI, or in Indonesia: LPS - Lembaga Penjaminan Simpanan). Thus, cash waqf funds in Islamic banks are more secure and guaranteed.

6. The distribution map and information network of Islamic banks is full of extensive experience so that the management of cash waqf is expected to not only optimize fund management, but also can streamline the distribution.

7. Positive image of Islamic banks is expected to create a positive image on the cash waqf movement. The alternative role of Islamic banks in cash waqf includes as Nazhir recipients, distributors, and waqf fund managers.

The change in the status of Islamic bank, which was previously only tasked with accommodating funds to become managers and distributors, is a common feature of the waqf bank model in Bangladesh. In addition, the situation in Bangladesh has some similarities with Indonesia. They are, among others, the majority of Muslim population and still shrouded in poverty. Islamic banks will later have full authority to become nazhir, starting from the recipients, managers, and distributors of cash waqf. This is none other than that in the implementation of collection, management, and distribution related to cash waqf to be carried out progressively because it is in a single door of an institution that is focused and based on a banking system that already has customers with principles of professionalism and trust. 
The fractions of the Cash Waqf Certificate (SWU) issued by Islamic banks can later be reached by all people, since the fractions ranging from IDR10.000, IDR25.000, IDR50.000, and IDR100.000. Fund management is also accompanied by cooperation with Islamic Guarantee Institutions to ensure no reduction in the principal value of cash waqf.

The Islamic bank can later carry out the management and development of cash waqf by distributing the funds collected in the form of soft loans as well as financing various types of investments, both in the form of mudharabah, musyarakah, etc. It must be realized that the waqf will be distributed to the public. For this reason, the management must be carried out professionally and accountably in a regulatory basis.

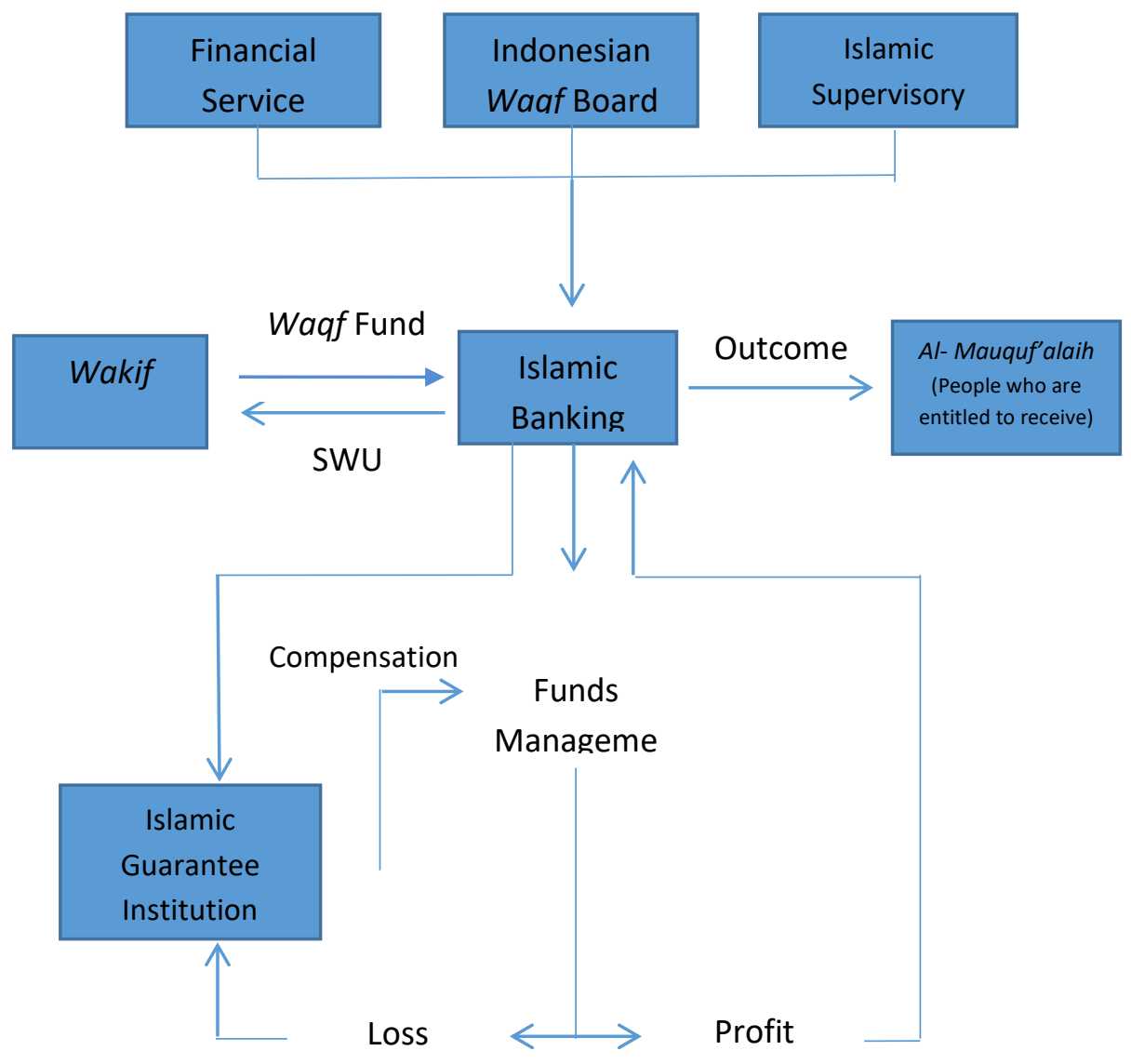

Image H.1: Management and Distribution of Cash Waqf in Islamic Banks in Indonesia 
Funding is carried out through the streamlining information networks and distribution maps. In terms of the distribution target, Islamic banks distribute it according to wakif and if wakif does not have any requirements, Islamic bank can determine unilaterally by prioritizing business capital, empowering education, health, and other economic empowerments. Islamic banks, in carrying out their activities, are monitored through integrated supervision between the Financial Services Authority (OJK), the Islamic Supervisory Board, and BWI. In terms of the mechanism of accountability to the public, the Islamic banks can rely on the accountability of the banking system and if necessary can take a way to report regularly to wakif and can request the services of independent public accountants to audit the Islamic bank.

The successful implementation of SWU in Bangladesh can be used as an example for Indonesia to carry out the management of this cash waqf. Islamic bank can support the development of cash waqf in Indonesia by collecting funds from the society, which consists of donating cash waqf directly and cash waqf deposits while still keeping the basic funds from the society to be managed over. The proceeds from the management of waqf funds are used to overcome problems related to education, health, economy, and social services. Hence, this is expected to realize social welfare in Indonesia.

\section{Conclusion}

Islamic banks currently are able to collect social funds that come from cash waqf. However, the social function of Islamic bank is limited only to raising funds. It has not been able to optimize the cash waqf in Indonesia. In addition to be collected by trusted and professional institutions, cash waqf must also be managed and distributed by a trusted and professional institution, one of which can be done by Islamic bank.

Assigning authority to Islamic bank as a nazhir can be a greatest solution to overcome the problem of cash waqf that has not been managed optimally nowadays. By becoming nazhir, Islamic bank can raise the funds and have the authority to manage and distribute the cash waqf. Furthermore, this system enables the advantages of bank to be maximized, in terms of professional ability in fund management, public trust, and networking. The success of the waqf bank in Bangladesh, the SIBL, can be used as a comparison and be adopted into a system of Islamic bank in Indonesia.

In order to realize the idea of converting the authority of Islamic Banking to become the nazhir, it is necessary to have a legal reform that regulates the authority of Islamic bank in managing cash waqf, both in Law Number 21 of 2008 on Islamic Banking and in Law Number 41 of 2004 on Waqf. 


\section{References}

\section{Books}

Abdul Ghofur Anshori, Hukum dan Praktik PerWakafan di Indonesia, Pilar Media, Yogyakarta, 2006.

Elsi Kartika Sari, Pengantar Hukum Zakat dan Wakaf, Grasindo, Jakarta, 2007.

F. Prihatini, (et.al.), Hukum Islam Zakat dan Wakaf, Collaboration between the Papas Sinar Mentari Publisher and the University of Indonesia's Faculty of Law Publishing Board, Jakarta, 2005.

Imam Suhadi, Wakaf Untuk Kesejahteraan Umat, PT. Dana Bhakti Prima Yasa, Yogyakarta, 2002.

Mardani, Hukum Ekonomi Syariah di Indonesia, Refika Aditama, Bandung, 2011.

Mustafa Edwin Nasution, Wakaf Tunai dan Sektor Volunteer, PSTTI-UI, Jakarta, 2006.

Revrisond Baswir, Ekonomi Kerakyatan sebagai Sistem Indonesia, Pustaka Pelajar, Yogyakarta, 1995.

Said Agil Husin al-Munawwar, Hukum Islam dan Pluralitas Sosial, Penamadani, Jakarta, 2004.

Soerjono Soekanto and Sri Mamudji, Penelitian Hukum Normatif: Suatu Tinjauan Singkat, PT. Raja Grafindo Persada, Jakarta, 2003.

2008.

Syamsuddin Mahmud, Dasar-Dasar Ilmu Ekonomi dan Koperasi, PT. Intermasa, Banda Aceh, 1986.

\section{Other Documents}

Ahmad Furqon, "Analisis Praktik Perwakafan Uang pada Lembaga Keuangan Syariah", Jurnal Walisongo, Vol. 19, No. 1, 2011.

Ali Amin Isfandiar, "Tinjauan Fiqh Muamalat dan Hukum Nasional tentang Wakaf di Indonesia", La Riba, Vol. 2, No. 1, 2008.

Dian Masyita, (et.al.), "A Dynamic Model for Cash Waqf Management as One of The Alternative Instruments for the Poverty Alleviation in Indonesia", The 23rd International Conference of The System Dynamics Society, Boston, 17 - 21 July 2005.

Jafril Khalil, "Social Investment Bank Limited (SIBL) di Bangladesh", Al-Awqaf, Vol. II, No. 02, 2009.

Lastuti Abubakar and Tri Handayani, "Perkembangan Transaksi Perbankan dan Implikasinya terhadap Pembaruan Hukum Perdata Indonesia", Justitia Jurnal Hukum, Vol. 1, No. 2, 2017.

M. A., Mannan, "Cash-waqf Certificate: Global Opportunities for Developing the Social Capital Market in 21st -Century Voluntary-sector Banking," Third Harvard University Forum on Islamic Finance, Harvard University, 2011. 
Juridical Study on the Optimization of Cash Waqf Management by Islamic Bank in Indonesia

, "Linking Islamic Commercial and Social Finance with Special Reference to Cash-Waqf as New Strategy of Interest-Free-Micro-Credit for Family Empowerment of The Poor Towards Establishing World Social Bank: A Case Study Approach", Journal of Islamic Monetary Economics and Finance, Vol. 3, Special Issue, 2018.

Muhyar Fanani, “Pengelolaan Wakaf Tunai”, Jurnal Walisongo, Vol. 19, No. 1, 2011. Sofyan Rizal, "Titik Temu dan Sinergi Ekonomi Islam dan Ekonomi Kerakyatan", Allqtishad, Vol. 3, No. 1, 2011.

Rashedul Hasana and Siti Alawiah Siraj, "Complexities of Waqf Development in Bangladesh", Journal of Emerging Economies and Islamic Research, Vol. 4, No. 3, 2016.

Syaugi Mubarak, "Demokrasi Ekonomi dalam Hukum Ekonomi Syari'ah", Risalah Hukum Fakultas Hukum Unmul, Vol. 6, No. 2, 2010.

Teguh Tresna Puja Asmara, Isis Ikhwansyah, and Anita Afriana, "Ease of Doing Business: Gagasan Pembaruan Hukum Penyelesaian Sengketa Investasi di Indonesia", University of Bengkulu Law Journal (UBELAJ), Vol. 4, No. 2, 2019.

Umi Nur Fadhilah, "Potensi Wakaf Tunai Capai Rp 180 Triliun", Republika, https://www.republika.co.id/berita/dunia-islam/wakaf/18/10/16/pgovmd384potensi-wakaf-tunai-capai-rp-180-triliun, accessed on 2 November 2018.

\section{Legal Documents}

The 1945 Constitution of the Republic of Indonesia

Law Number 41 of 2004 on Waqf

Law Number 21 of 2008 on Islamic Banking.

Government Regulation Number 42 of 2006 on the Implementation of the Law Number 41 of 2004 on Waqf. 